Old Dominion University

ODU Digital Commons

Psychology Faculty Publications

Psychology

2006

\title{
Predictors of Paternal Involvement in Childcare in Dual-Earner Families With Young Children
}

Julie N.Jacobs

Old Dominion University

Michelle L. Kelley

Old Dominion University, mkelley@odu.edu

Follow this and additional works at: https://digitalcommons.odu.edu/psychology_fac_pubs

Part of the Child Psychology Commons, and the Family, Life Course, and Society Commons

\section{Repository Citation}

Jacobs, Julie N. and Kelley, Michelle L., "Predictors of Paternal Involvement in Childcare in Dual-Earner Families With Young Children" (2006). Psychology Faculty Publications. 65.

https://digitalcommons.odu.edu/psychology_fac_pubs/65

\section{Original Publication Citation}

Jacobs, J. N., \& Kelley, M. L. (2006). Predictors of paternal involvement in childcare in dual-earner families with young children. Fathering: A Journal of Theory, Research, and Practice about Men as Fathers, 4(1), 23-47. doi:10.3149/fth.0401.23

This Article is brought to you for free and open access by the Psychology at ODU Digital Commons. It has been accepted for inclusion in Psychology Faculty Publications by an authorized administrator of ODU Digital Commons. For more information, please contact digitalcommons@odu.edu. 


\title{
Predictors of Paternal Involvement in Childcare in Dual-Earner Families with Young Children
}

\author{
JULIE N. JACOBS \\ Michelle L. KeLLey \\ Old Dominion University
}

\begin{abstract}
Dual-earner parents $(N=119)$ of preschool children enrolled in licensed childcare centers completed anonymous questionnaires that examined work and family variables as related to paternal involvement in three areas: engagement (i.e., one-on-one interaction with the child), responsibility (i.e., taking care of the child's needs), and accessibility (i.e., being available to the child without directly interacting). Paternal responsibility was predicted by beliefs about fathering and structural variables (e.g., hours fathers and mothers worked). The percentage of time fathers spent as their child's primary caregiver was predicted by structural variables (e.g., mothers' work hours) and belief variables (e.g., men's beliefs about fathering and fathers' parenting self-efficacy). Paternal engagement and accessibility were not significantly predicted by any of the constructs examined.
\end{abstract}

Keywords: fathering, paternal involvement, paternal responsibility

\begin{abstract}
Sixty-two percent of mothers with children age six and under were in the labor force in 2004 (U.S. Department of Labor, 2005). As a result, men in dual-earner couples are now expected to be co-parents (Pleck \& Pleck, 1997). Although fathers in two-income families have gradually increased their involvement in childcare (see Cabrera, Tamis-LeMonda, Bradley, Hofferth, \& Lamb, 2000; Pleck, 1997; Sandberg \& Hofferth, 2001), even in dual-earner couples the percentage of childcare men perform is seldom proportionate to that of their wives (Pleck \& Masciadrelli, 2004).

The authors would like to thank Cathy G. Cooke for her comments on an earlier version of this manuscript and the parents and daycare centers that took part in this research.

Correspondence concerning this article should be addressed to Michelle L. Kelley, Old Dominion University, Norfolk, VA 23529-0267. Electronic mail: mkelley@odu.edu.

Fathering, Vol. 4, No. 1, Winter 2006, 23-47.

(C) 2006 by the Men's Studies Press, LLC. All rights reserved.
\end{abstract}


Understanding the determinants of fathers' involvement is critical given that fathers' participation in childcare is related to children's academic achievement (McBride, Schoope-Sullivan, \& Ho, 2005), psychological adjustment (Downer \& Mendez, 2005; Flouri \& Buchanan, 2003a; Wenk, Hardesty, Morgan, \& Blair, 1994), and aggressive behavior (Flouri \& Buchanan, 2003b). Moreover, the ways in which fathers influence their children's social (e.g., Parke et al., 2004) and cognitive (Dubowitz et al., 2001) development appear uniquely different from mothers. Also, among dual-earner couples, father involvement may mediate the effects of maternal depression on children's behavior (Mezulis, Hyde, \& Clark, 2004).

Father involvement is also related to lower maternal stress (e.g., Kalil, ZiolGuest, \& Coley, 2005). In addition, discrepancies between expected and actual father involvement in childrearing are related to mothers' perceptions of inequity in the division of labor (Milkie, Bianchi, Mattingly, \& Robinson, 2002). Maternal stress, in turn, appears associated with increases in marital conflict (Hoffman, 1989; Milkie et al., 2002). Thus, it appears that father involvement not only has positive associations with child outcomes but may have important benefits for their partners and for family processes.

Although previous investigations have demonstrated the benefits of father involvement, in general much of this research has not been theory-driven (e.g., Baruch \& Barnett, 1981). A number of investigators have proposed models of father involvement (e.g., Doherty, Kouneski, \& Erickson, 1998); however, perhaps the most recognized model is that of Lamb and colleagues (e.g., Lamb, Pleck, Charnov, \& Levine, 1985, 1987). According to Lamb et al., the first domain of paternal involvement, termed engagement, is characterized by undivided attention to the child (i.e., reading to the child). A less direct form of involvement that does not involve one-on-one interaction with the child is classified as accessibility (i.e., the father is reading the newspaper in the same room in which the child is watching television). The last category of father involvement described by Lamb and colleagues, responsibility, involves taking care of the child's needs such as buying the child clothes and scheduling pediatrician appointments.

Lamb and colleagues (1987) also specify four categories of influence that shape father involvement. These include the fathers' motivation to be involved in their children's lives; skills and self-confidence in the fathering role; social support and stresses; and institutional factors such as job characteristics. To date only one study has examined interrelationships between the four categories of influence as related to father involvement within the same study. Specifically, using data from the Child Development Supplement (CDS) of the Panel of Income Dynamics (PSID) (Hofferth, 1998), McBride, Schoppe, Ho, and Rane (2004) examined how each of the four factors described by Lamb and colleagues and demographic factors contributed to five aspects of father involvement (i.e., responsibility for child management tasks, warmth and affection toward the child, housework completed with the child, childcentered activities performed with the child, and parental monitoring). The McBride et al. study provided valuable information on the relative importance of each category of influence; however, it was limited by items that were previously generated for the PSID-CDS. The present study expands on the earlier study by examining 
how the four categories of influence hypothesized by Lamb et al. are related to father involvement using established scales of each of the constructs of interest.

\section{Motivation}

Research has demonstrated that fathers' motivation to be involved in fathering is more important than their spouses' beliefs in determining the amount of time fathers are involved with their children (Cook, Jones, Dick, \& Singh, 2005; McBride et al., 2004). Two measures of motivation are examined in the present study. First, men's commitment to and identification with the fatherhood role is associated with their level of paternal involvement (Fox \& Bruce, 2001). Specifically, men who have more progressive beliefs about fatherhood report greater participation in childcare than men with more traditional beliefs (e.g., Aldous, Mulligan, \& Bjarnason, 1998; Crouter, Perry-Jenkins, Huston, \& McHale, 1987; Levy-Shiff \& Israelashvili, 1988; Minton \& Pasley, 1996; Pleck \& Masciadrelli, 2004).

Another factor that may also influence men's motivation to be involved with their children is career saliency. Fathers who are less emotionally attached to their jobs may spend more time with their children if they are able. For instance, Feldman, Nash, and Aschenbrenner (1983) found low job salience predicted greater participation in infant care. In contrast, fathers who are highly invested in and derive more of their sense of self-worth from their careers may be less invested in fathering (Hochschild, 1997).

\section{SKILlS AND SELF-CONFIDENCE}

Parenting self-efficacy and parenting satisfaction are two components of skills and self-confidence that affect father involvement. Studies have shown parenting selfefficacy (i.e., the degree to which a parent believes he/she is able to care for the child's emotional and physical needs) is associated with paternal involvement (e.g., Beitel \& Parke, 1998; Ehrenberg, Gearing-Small, Hunter, \& Small, 2001). Among mothers, those with high parenting self-efficacy were more responsive and stimulating with their children (Donovan, 1981; Donovan \& Leavitt, 1985; Unger \& Wandersman, 1985) and more involved and direct in their parenting interactions (Mash \& Johnston, 1983). Fathers report lower levels of parenting efficacy than do mothers (Hudson, Elek, \& Fleck, 2001); similar to mothers, however, fathers who perceive themselves as having greater skill at childcare report greater involvement in and responsibility for childcare tasks (Sanderson \& Thompson, 2002).

Although men's satisfaction with parenting has received little attention, the available literature suggests that higher satisfaction with parenthood is associated with greater involvement (e.g., Russell, 1983; Sagi, 1982). Nevertheless, better understanding of the relationship between parenting satisfaction and father involvement is necessary.

\section{SOCIAL SUPPORTS AND STRESSES}

Mothers' beliefs regarding fathering, marital satisfaction, and work-family conflict are social supports and stresses that have been found to influence paternal involve- 
ment. In general, women's beliefs about how involved their partners should be in fathering are related to men's involvement (e.g., Allen \& Hawkins, 1999; Beitel \& Parke, 1998; Hofferth, 2003). Often designated maternal gatekeeping, mothers who report more traditional gender role beliefs typically have partners who are less involved in childcare (Allen \& Hawkins, 1999; Barnett \& Baruch, 1987; Beitel \& Parke, 1998; but see Aldous et al., 1998; Bonney, Kelley, \& Levant, 1999; Marsiglio, 1991; Pleck, 1997).

In addition, positive emotional interactions with a partner may affect men's state of mind and reinforce their desire to be involved in all facets of family life (e.g., Aldous et al., 1998). Some studies have shown that fathers who report greater marital satisfaction report more participation in childrearing (e.g., Bonney et al., 1999; Levy-Shiff \& Israelashvili, 1988). Greater marital satisfaction has been related to higher quality of father-child interactions (Jump \& Haas, 1987; McBride \& Mills, 1993). However, other research has found that, for men, more time spent in childcare is associated with lower marital satisfaction (Nangle, Kelley, Fals-Stewart, \& Levant, 2003; Russell, 1983).

At the same time, the relationship between marital satisfaction and involvement in childcare may be affected by other variables. Hoffman (1989) argued that men with more traditional views of fatherhood and who took greater responsibility for childcare reported higher levels of marital dissatisfaction when increased paternal responsibility was due to their wives' employment. Similarly, fathers who believe work involvement is the primary mechanism for fulfilling spouse and parenting roles (i.e., the traditional "provider" role) may feel resentful about taking responsibility for childcare (e.g., Crouter et al., 1987).

Additionally, the work-family conflict literature suggests two distinct elements that may create work and family tension. These are work interference with family (WIF) and family interference with work (FIW) (Frone, Yardley, \& Markel, 1997). Although the competing demands of work and family are widely recognized in working mothers (e.g., Noor, 2004) and perceptions of work-family conflict are comparable in mothers and fathers (Hart \& Kelley, 2006; Hill, Hawkins, Martinson, $\&$ Ferri, 2003), little research has examined men's work-family strain. We do know that the more hours mothers work outside the home, the more time fathers spend taking care of children (Beitel \& Parke, 1998; Bonney et al., 1999; Pleck, 1997). Gendered beliefs regarding men's and women's roles maintain that work-family conflict (WIF) would be more salient for men, whereas family-to-work conflict (FIW) would be more significant for women (Nordenmark, 2004).

\section{INSTITUTIONAL FACTORS}

Although institutional factors include workplace policies (e.g., parental leave, flexibility of work schedules), in particular, research has examined fathers' work hours as related to men's involvement in childcare. The more hours men spend at work, the less involved they are in the care of young children (e.g., Aldous et al., 1998; Berry \& Rao, 1997; Bonney et al., 1999; Pleck \& Masciadrelli, 2004; Russell \& Hwang, 2004). In fact, Yeung, Sandberg, Davis-Kean, and Hofferth (2001) showed that, for every hour a father worked per week, there was a one- minute decrease in the amount 
of time fathers spent with the target child on weekdays. As might be expected, the more hours mothers spend working, the greater fathers' involvement in childcare (e.g., Bonney et al., 1999; Coltrane, 1996; Parke, 2002).

\section{Paternal Engagement, Accessibility, And Responsibility in ChildCARE}

The present research examined the aforementioned variables as related to the three aspects of fathering described by Lamb et al. (1985, 1987-engagement, accessibility, and responsibility). Historically, a common way to assess father involvement was via mothers' and fathers' reports of the percentage of time men spend as their child's primary caregiver (see Coltrane, 1996). We also asked mothers and fathers to report the percentage of time fathers spent as the child's primary caregiver to provide information on how the categories of influence described by Lamb and colleagues related to this more researched aspect of father involvement.

It was hypothesized that fathers' involvement (i.e., engagement, accessibility, responsibility, percentage of time as the child's primary caregiver) would be associated with (1) greater motivation to be involved in childcare (i.e., more progressive beliefs about the role of fathering as reported by fathers, lower career saliency as reported by fathers); (2) greater perceived skill and self-confidence in the fathering role (i.e., higher parenting self-efficacy as reported by both fathers and mothers, greater satisfaction in the parenting role as reported by both fathers and mothers); (3) more support from spouses and lower stress (i.e., higher levels of marital satisfaction as reported by both mothers and fathers, more progressive beliefs about fathering as reported by mothers, greater career saliency as reported by mothers, less work-family conflict as reported by both fathers and mothers); and (4) institutional factors (fewer work hours by fathers, more work hours by women). Because research has demonstrated that fathers' beliefs are more important than that of their spouses in determining the amount of time fathers are involved with their children (Cook, Jones, Dick, \& Singh, 2005), we performed hierarchical regressions with the variables hypothesized to assess motivation entered in the first step followed by skills and self-confidence, support and stress, and institutional factors.

\section{METHOD}

\section{PARTICIPANTS}

Participants were 119 dual-earner couples who lived with a biological child (67 girls, 52 boys) between the ages of one and four ( $M=2.6$ years; $S D=1.0$ year). All parents were employed outside the home and had children who attended one of several licensed daycare centers in southeastern Virginia.

Mean age of fathers was 35.1 years $(S D=6.6$; Range $=22$ to 54$)$. Educational level of the fathers was as follows: three $(2.5 \%)$ had attended high school; 17 (14.3\%) were high school graduates; 43 (36.1\%) had attended college; 33 (27.7\%) were college graduates; $13(10.9 \%)$ held a master's degree; and $10(8.4 \%)$ had completed a doctoral degree. Fathers worked an average of 46.6 hours per week outside the home $(S D=10.0$; Range $=15$ to 84$)$. Three fathers did not report the number of 
hours worked outside the home. Ninety-seven (81.5\%) men were White; 15 (12.6\%) were African American; five (4.2\%) were Latino; one (0.8\%) was Asian American; and one $(0.8 \%)$ had an unspecified racial/ethnic identity. The mean family income of the couples who reported this information $(n=97)$ was $\$ 86,119$ per year $(S D=$ $\$ 57,527$; Range $=\$ 25,000$ to $\$ 500,000)$.

Mothers had a mean age of 34.0 years $(S D=6.2$; Range $=22$ to 54$)$. One mother did not report her age. The educational level of mothers was as follows: six (5.0\%) had completed high school; 41 (34.5\%) had attended college; 43 (36.2\%) were college graduates; $16(13.4 \%)$ held a master's degree; and $13(10.9 \%)$ had completed a doctoral degree. Mothers worked an average of 38.7 hours outside the home $(S D=9.4$; Range $=6$ to 80$)$. One mother did not report the number of hours worked outside the home. Ninety-five (79.8\%) mothers were White; 15 (12.6\%) were African American; two (1.7\%) reported ethnicities as American Indian or Alaskan native; 2 (1.7\%) were Asian American; 2 (1.7\%) were Hispanic or Latino; one $(0.8 \%)$ reported ethnicity as Native Hawaiian or other Pacific Islander; and two $(1.7 \%)$ had an unspecified racial/ethnic background.

The sample consisted of 113 married couples and six cohabitating couples. Sixty-eight (57.1\%) of the couples had two or more children; 51 (42.9\%) had one child. Couples with more than one child in the selected age range were asked to answer the questions as they pertained to their youngest child.

\section{OVERVIEW of MEASURES}

Mothers and fathers independently completed questionnaires that assessed the degree to which fathers are involved in the care of their young children, parental beliefs about fathering, career saliency, marital satisfaction, work-family conflict, parenting self-efficacy and parenting satisfaction.

\section{MEASURES}

Paternal Index of Childcare Inventory (PICCI). A version of Radin's PICCI questionnaire (Radin \& Goldsmith, 1985) that was modified by Nangle et al. (2003) was employed to assess paternal engagement, accessibility, and responsibility. The modified version of the PICCI was a combination of the original PICCI items, items from McBride's Paternal Responsibility Scale (McBride \& Mills, 1993), and additional items developed to assess aspects of paternal involvement with young children. Items measuring engagement include "bathes the child" and "reads to child." Sample statements from the accessibility subscale are "monitors child while he/she is playing" and "is available to the child if he/she becomes upset." Sample items from the responsibility scale are: "buys child clothes" and "determines appropriate activities for the child." Both mothers and fathers answered each item using the following five-point scale: 1 = mother always does, 2 =mother usually does, $3=$ both parents share equally, $4=$ father usually does, and $5=$ father always does. Higher scores reflected that the father performed the childcare activity more often.

For the engagement subscale (12 items), mean scores were $33.9(S D=4.8)$ for fathers and $32.1(S D=5.1)$ for mothers out of a possible 60 points. The average 
Accessibility subscale score was $23.3(S D=3.6)$ for fathers and $21.7(S D=3.7)$ for mothers with a total possible score of 40 points. One item from the accessibility subscale was deemed to be a poor fit as determined by correlations with other subscale items and reliability information; therefore, the final accessibility subscale consisted of eight items. Eighteen items were included on the responsibility subscale. The mean responsibility subscale score was $44.5(S D=8.4)$ for fathers and $40.2(S D=$ 9.3) for mothers out of a total of 90 points possible. Higher scores on these subscales indicate greater paternal involvement. Alphas for fathers and mothers were .81 and .85 for the engagement subscale, .78 and .78 for the accessibility subscale, and .86 and .89 on the responsibility subscale, respectively. Alphas were comparable to those reported by Nangle and associates (2003).

Beliefs Concerning the Parental Role Scale (BCPR). The 26-item BCPR (Bonney, 1997; Nangle et al., 2003) assesses parents' beliefs regarding appropriate roles of mothers and fathers in the care of young children. Statements such as "It is important for a father to spend quality time (one to one) with his children every day" and "It is more important for a mother rather than a father to stay home with an ill child" were rated on a scale from $1=$ Agree Strongly to $5=$ Disagree Strongly. Mean scores on the BCPR were $109.7(S D=10.9)$ for fathers and $112.8(S D=8.8)$ for mothers out of a total of 130 points. Lower scores indicate more traditional (i.e., less liberal) views of men's involvement with children. Comparable to those reported by Bonney et al. (1999), alphas for the present study were .84 for fathers and .75 for mothers.

Career Salience Scale (CSS). The CSS (Greenhaus, 1971) is a six-item scale that measures the significance of work and career in a person's life. Items are scored $1=$ Strongly Disagree to $5=$ Strongly Agree. A sample item is "I enjoy thinking about and making plans about my future career." Mean scores on the CSS were $9.0(S D=$ $2.5)$ for fathers and $8.4(S D=2.2)$ for mothers out of a possible 25 points. Alphas for the CSS, .66 for fathers and .59 for mothers, were slightly lower than those reported in previous work utilizing this measure $(\alpha=.81$; Greenhaus, 1971; Greenhaus \& Simon, 1977).

Parenting Sense of Competency Scale (PSOC). The PSOC is a 16-item scale (Gibaud-Wallston \& Wandersman, 1978) that measures both parental satisfaction and parental self-efficacy. Nine of the items assess parental satisfaction (e.g., "Being a parent makes me tense and anxious"-reverse scored). Seven items assess parental self-efficacy (e.g., "I meet my own personal expectations for expertise in caring for my child"). Items were rated from $1=$ Strongly Agree to $6=$ Strongly Disagree. In the original scoring of the PSOC, lower scores reflect higher parenting satisfaction and better parenting self-efficacy; however, to make the scoring consistent with the hypotheses and for ease of interpretation, in the present study items were coded so that the higher the summed total score for each dimension, the higher the parenting satisfaction and greater parenting self-efficacy. Out of a total of 54 possible points, mean satisfaction subscale scores were $39.9(S D=6.9)$ for fathers; mothers' mean satisfaction subscale scores were $39.5(S D=6.6)$. Means on the self-efficacy subscale were $29.5(S D=5.0)$ for fathers and $29.8(S D=6.0)$ for mothers out of 42 
points possible. Alphas were .81 for fathers and .77 for mothers on the parental satisfaction subscale. Reliability coefficients for the parental self-efficacy subscale were .75 for fathers and .80 for mothers. These alphas are comparable to those found in previous research (e.g., Cutrona \& Troutman, 1986; Johnston \& Mash, 1989; Ohan, Leung, \& Johnston, 2000).

Kansas Marital Satisfaction Scale (KMS). The KMS (Schumm et al., 1986) is a threeitem questionnaire that assesses an individuals' satisfaction with their spouse and marriage. Items are scored from $1=$ Extremely Dissatisfied to $7=$ Extremely Satisfied. A sample item is "How satisfied are you with your marriage?" Out of 21 possible points, fathers' total mean KMS score was $17.1(S D=4.2)$; mothers' mean KMS score was $17.1(S D=3.7)$. For both mothers and fathers, alphas in the present study were .96 .

Work-Family Conflict (W-F). The W-F conflict scale (Kopelman, Greenhaus, \& Connelly, 1983) measures two dimensions of work-family interference: work to family and family to work. Participants rated items such as "After work, I come home too tired to do some of the things I'd like to do" and "My personal demands are so great that it takes away from my work" on a five-point scale from $1=$ Strongly Disagree to $5=$ Strongly Agree. The first two items assessed the amount of interference from family to work, and the last two items measured the amount of interference from work to family. For both dimensions higher scores indicate greater interference. Total scores for each parent were obtained by combining the scores of both dimensions. Fathers' mean score was $10.7(S D=2.8)$, and mothers' mean score was $10.8(S D=2.7)$, out of a total of 20 points. Reliability coefficients for the W-F conflict scale were low (.51 for fathers, .57 for mothers) but comparable to previous research (Nangle et al., 2003).

Demographic Questionnaire. The demographic questionnaire assessed parents' age, education, race/ethnicity, number of children, employment information, and family income. To provide information that was comparable to previous research assessing fathers' involvement with their children, each parent also completed the following item: "Totaling 100 percent, what is the percentage of time that you and your partner spend as the child's primary caregiver?" However, only the percentage of time that fathers spent as the child's primary caregiver was used in analyses.

\section{PROCEDURE}

A survey packet including a description of the study and the questionnaires was placed in the cubby of each child in the specified age range attending the participating childcare centers. As an incentive to participate, a coloring book was placed on the top of each packet. At four childcare centers in which policies would not allow placing the survey packet in the child's cubby, a flyer that announced the study was placed in the child's cubby. Parents at these four childcare centers were able to obtain a survey packet from the childcare staff.

Parents were instructed to answer the questionnaires independently of their partner and then seal the questionnaires in one of two envelopes provided for the cou- 
ples. Parents then placed the two separate sealed envelopes into a large envelope that was provided and returned the completed surveys to the childcare center. Parents were instructed not to write their names or other identifying information on the survey. After one week, a reminder notice was placed in the children's cubbies.

A total of 997 survey packets were distributed. One hundred nineteen usable packets were returned. Thirty-three additional packets were returned but were not usable (i.e., parents did not reside together, only one parent completed the survey, and so forth).

\section{RESULTS}

\section{Correlations among the Predictor Variables}

Prior to hypothesis testing, correlational analyses were conducted to examine the pattern of relationships between the variables. The more hours mothers' worked outside the home per week, (1) the higher fathers' self-efficacy in the parenting role, (2) the more liberal mothers' beliefs concerning men's roles, and (3) the more career saliency mothers reported. Fathers who reported greater satisfaction in the parenting role reported (1) more liberal beliefs concerning fathering, (2) less work-family conflict, and (3) greater confidence in the parental role. Mothers' reports of parenting satisfaction and self-efficacy were positively and significantly correlated. Moreover, mothers' marital satisfaction and parental satisfaction were significantly correlated. As one might expect, the more hours fathers worked outside the home, the more work-family conflict men experienced. It is interesting to note that the more confident men were in the parenting role, the less work-family conflict their spouses reported. Also, mothers reported being more satisfied in the parental role when they experienced less work-family conflict. Fathers' and mothers' independent reports of career saliency, marital satisfaction, parenting satisfaction, and parenting self-efficacy were positively and significantly related (see Table 1).

\section{Correlations among Partners' Reports of Engagement, ACCESSIBILITY, AND RESPONSIBILITY}

Fathers' and mothers' reports of each of the types of paternal involvement were significantly correlated. Specifically, correlations between parents were .63 for engagement, .49 for accessibility, and .63 for responsibility, with a mean correlation of .58 . Fathers' and mothers' reports of the percentage of time fathers served as the child's primary caregiver were also positively and significantly related, $r(118)=.61, p<$ .01 . Therefore, fathers' and mothers' reports of each of the types of paternal involvement examined were combined for analyses.

\section{Correlations among the Predictor Variables And PATERNAL INVOLVEMENT}

Motivational Factors. Table 2 shows the correlations among the predictor variables and paternal engagement, accessibility, responsibility, and the percentage of time 
JACOBS and KELLEY

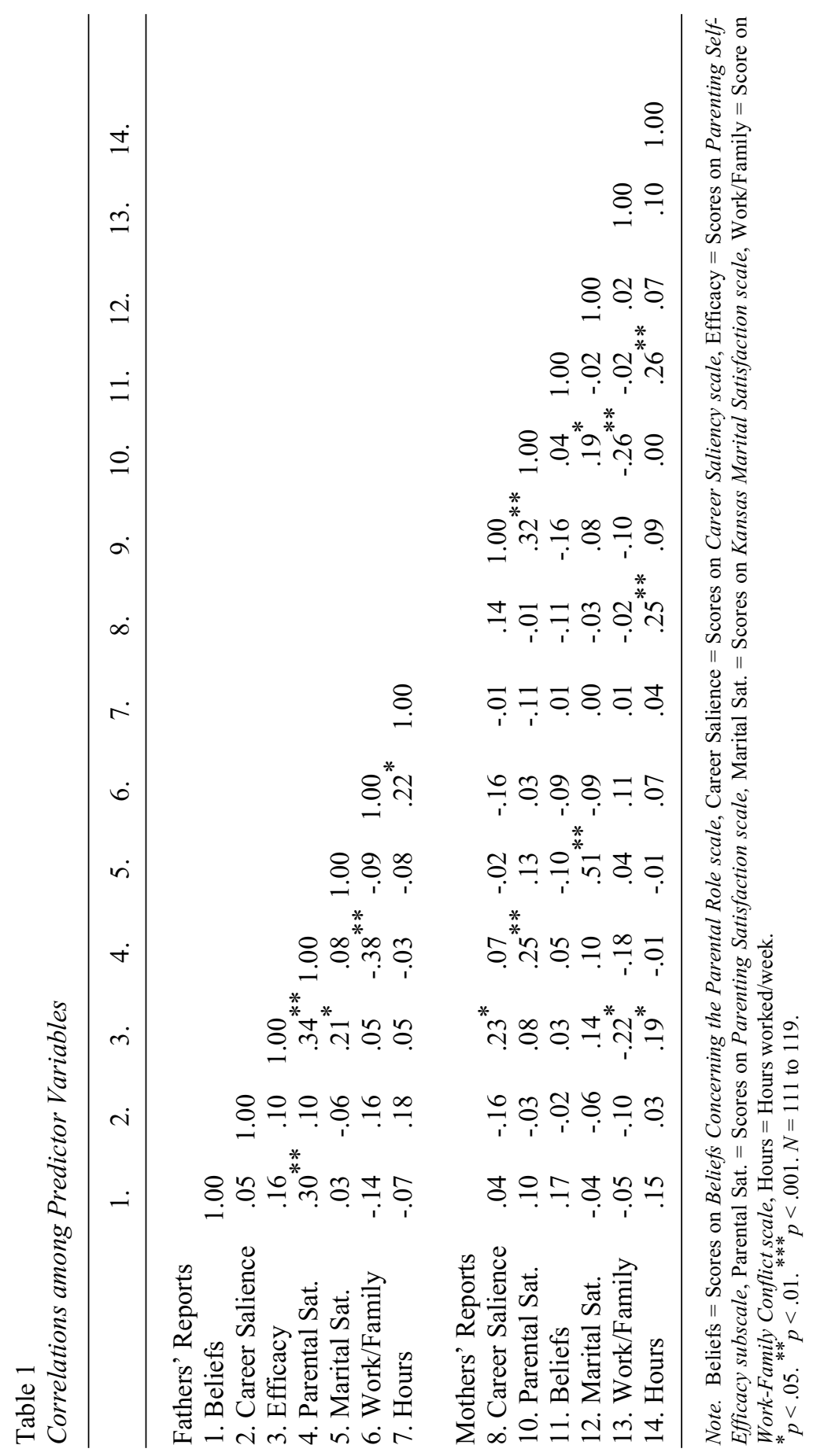


Predictors of PATERNAL INVOLVEMENT

Table 2

Correlations among Predictor Variables and Reports of Paternal Involvement

\begin{tabular}{|c|c|c|c|c|}
\hline & Engagement & Accessibility & Responsibility & $\begin{array}{c}\text { Primary } \\
\text { Caregiver }\end{array}$ \\
\hline \multicolumn{5}{|l|}{ Fathers' Reports } \\
\hline Beliefs & $.22^{*}$ & $.20^{*}$ & $.33^{* * *}$ & $.30^{* *}$ \\
\hline Career Salience & .05 & .00 & .17 & .03 \\
\hline Efficacy & $.23^{*}$ & $.23^{*}$ & $.20^{*}$ & $.29^{* *}$ \\
\hline Parental Sat. & .11 & .17 & .13 & .16 \\
\hline Marital Sat. & $.19^{*}$ & .12 & .10 & .09 \\
\hline Work/Family & -.05 & -.16 & -.06 & -.14 \\
\hline Hours & -.16 & -.13 & $-.28^{* *}$ & -.15 \\
\hline \multicolumn{5}{|l|}{ Mothers' Reports } \\
\hline Career Salience & .00 & -.01 & $.18^{*}$ & .12 \\
\hline Efficacy & .02 & -.05 & -.13 & .01 \\
\hline Parental Sat. & .04 & -.02 & .06 & .06 \\
\hline Beliefs & .08 & .08 & -.08 & .12 \\
\hline Marital Sat. & .12 & .00 & .08 & .13 \\
\hline Work/Family & .05 & .03 & -.01 & .08 \\
\hline Hours & .13 & $.20^{*}$ & $.31^{* *}$ & $.43^{* * *}$ \\
\hline
\end{tabular}

Note . Beliefs = Scores on Beliefs Concerning the Parental Role scale, Career Salience = Scores on Career Saliency scale, Efficacy = Scores on Parenting Self-Efficacy subscale, Parental Sat. = Scores on Parenting Satisfaction subscale, Marital Sat. = Scores on Kansas Marital Satisfaction scale, Work/Family $=$ Scores on Work-Family Conflict scale, Hours $=$ Number of hours worked/week. ${ }^{*} p<.05 .{ }^{* *} p<.01 .{ }^{* * *} p<.001 . N=111$ to 119 .

fathers spent as the primary caregiver. In support of hypotheses, more liberal beliefs about the parenting role as reported by fathers were positively and significantly associated with fathers' engagement, accessibility, responsibility, and percentage of time serving as primary caregivers for their children. Fathers' reports of career salience, however, were not significantly associated with involvement with their children and thus did not support hypotheses.

Skills and Self-Confidence. In support of hypotheses, fathers' parenting self-efficacy was positively related to father involvement and the percentage of time the father served as the child's primary caregiver. The more confident fathers felt in the parenting role, the more involved they were in their children's lives. In contrast, however, satisfaction in the parenting role by both fathers and mothers and mothers' reports of parenting self-efficacy were not significantly associated with how involved fathers were with their young children, which failed to support hypotheses. 
Social Support and Stresses. In contrast to what was expected, mothers' beliefs regarding how involved fathers should be in parenting and work-family conflict for both parents were not significantly associated with father involvement. Likewise, mothers' marital satisfaction was not significantly associated with any of the fathering dimensions investigated and did not support hypotheses. In contrast to their wives, men's marital satisfaction was significantly and positively related to engagement in fathering, thereby partially supporting hypotheses. In addition, mothers' career saliency scores were positively and significantly related to fathers' responsibility scores.

Institutional Factors. Partial support of hypotheses were found in that the more hours fathers worked outside the home, the less responsibility fathers took in childcare. Furthermore, hypotheses were partially supported by the findings that the number of hours mothers worked outside the home was significantly and positively related to fathers' accessibility, responsibility, and percentage of time spent as the children's primary caregiver.

\section{Results of Hierarchical Regression Analyses}

To better understand how each of the blocks of variables discussed by Lamb and colleagues $(1985,1987)$ explained father involvement, each block was entered into a regression equation. Because our primary focus was the degree to which motivational variables influence father involvement, motivational variables were entered in the first step of the hierarchical regression analyses. Motivational variables were followed by skills and self-confidence in parenting in step 2, social support and stress variables in step 3 , and institutional factors in the final step of the equations.

Predictors of Paternal Engagement. As shown in Table 3, the equations predicting paternal engagement (i.e., motivational variables, skills and self-confidence in parenting, social support and stress, and institutional factors) were not significant.

Predictors of Paternal Accessibility. No support was found for the hypothesized blocks as significant predictors of paternal accessibility (see Table 4).

Predictors of Paternal Responsibility. As shown in Table 5, each equation significantly predicted paternal responsibility. Specifically, the first equation (i.e., motivational variables) accounted for $9 \%$ of the variance, $F(3,105)=4.71, p<.01, R=$ $.35, \operatorname{Adj} . R^{2}=.09$. The only motivational variable that significantly predicted paternal responsibility was fathers' beliefs concerning the parental role $\left(\beta=.28, s r_{i}{ }^{2}=\right.$ $.08)$. The second equation, which assessed skills and self-confidence in addition to motivation variables, was also significant, $F(7,101)=3.17, p<.01, R=.43, \operatorname{Adj} . R^{2}$ $=.12, \Delta R^{2}=.06$. Specifically, fathers' efficacy in childcare $\left(\beta=.26, s r_{i}{ }^{2}=.05\right)$ significantly predicted paternal responsibility; fathers' beliefs concerning the parental role approached significance $\left(\beta=.21, s r_{i}^{2}=.03\right)$. The third equation was also significant, accounting for $10 \%$ of the variance, $F(12,96)=2.04, p<.05, R=.45, A d j . R^{2}$ 
Predictors of Paternal Involvement

Table 3

Results of Hierarchical Regression Analyses Predicting Paternal Engagement

\begin{tabular}{|c|c|c|c|c|c|c|c|}
\hline Variables & $\beta$ & $R$ & $R^{2}$ & Adj. $R^{2}$ & $\Delta R^{2}$ & $F$ & $s r_{i}^{2}$ \\
\hline Step 1 & & .22 & .05 & .02 & 1.76 & & \\
\hline F Beliefs & $.21 *$ & & & & & & .04 \\
\hline F Career Salience & .00 & & & & & & .00 \\
\hline M Career Salience & -.09 & & & & & & .01 \\
\hline Step 2 & & .33 & .11 & .05 & .06 & 1.81 & \\
\hline F Beliefs & .17 & & & & & & .02 \\
\hline F Career Salience & -.02 & & & & & & .00 \\
\hline M Career Salience & -.09 & & & & & & .01 \\
\hline F Parental Sat. & -.07 & & & & & & .00 \\
\hline M Parental Sat. & -.05 & & & & & & .00 \\
\hline F Efficacy & $.27 *$ & & & & & & .06 \\
\hline M Efficacy & -.01 & & & & & & .00 \\
\hline Step 3 & & .37 & .14 & .03 & .03 & 1.26 & \\
\hline F Beliefs & .15 & & & & & & .02 \\
\hline F Career Salience & .01 & & & & & & .00 \\
\hline M Career Salience & -.07 & & & & & & .00 \\
\hline F Parental Sat. & -.12 & & & & & & .01 \\
\hline M Parental Sat. & -.03 & & & & & & .00 \\
\hline F Efficacy & $.28 *$ & & & & & & .05 \\
\hline M Efficacy & -.02 & & & & & & .00 \\
\hline M Beliefs & .05 & & & & & & .00 \\
\hline F Marital Sat. & .08 & & & & & & .00 \\
\hline M Marital Sat. & .00 & & & & & & .00 \\
\hline F Work/Family & -.12 & & & & & & .01 \\
\hline M Work/Family & .05 & & & & & & .00 \\
\hline Step 4 & & .41 & .17 & .04 & .03 & 1.34 & \\
\hline F Beliefs & .13 & & & & & & .01 \\
\hline F Career Salience & .04 & & & & & & .00 \\
\hline M Career Salience & -.11 & & & & & & .01 \\
\hline F Parental Sat. & -.09 & & & & & & .00 \\
\hline M Parental Sat. & -.07 & & & & & & .00 \\
\hline F Efficacy & $.26^{*}$ & & & & & & .04 \\
\hline M Efficacy & .00 & & & & & & .00 \\
\hline M Beliefs & .04 & & & & & & .00 \\
\hline F Marital Sat & .08 & & & & & & .00 \\
\hline M Marital Sat. & .01 & & & & & & .00 \\
\hline F Work/Family & -.07 & & & & & & .00 \\
\hline M Work/Family & .03 & & & & & & .00 \\
\hline F Hours & -.18 & & & & & & .03 \\
\hline M Hours & .06 & & & & & & .00 \\
\hline
\end{tabular}

Note $. \mathrm{F}=$ Fathers' reports, $\mathrm{M}=$ Mothers' reports, Beliefs $=$ Scores on Beliefs Concerning the Parental Role scale, , Career Salience $=$ Scores on Career Saliency scale, , Parental Sat. = Scores on Parenting Satisfaction subscale, Efficacy = Scores on Parenting Self-Efficacy subscale, Marital Sat. = Scores on Kansas Marital Satisfaction scale, Work/Family = Scores on Work-Family Conflict scale, Hours = Hours worked/week.

$* p<.05 . N=109$. 
Table 4

Results of Hierarchical Regression Analyses Predicting Paternal Accessibility

\begin{tabular}{|c|c|c|c|c|c|c|c|}
\hline Variables & $\beta$ & $R$ & $R^{2}$ & $\operatorname{Adj} . R^{2}$ & $\Delta R^{2}$ & $F$ & $s r_{i}^{2}$ \\
\hline Step 1 & & .18 & .03 & .01 & 1.21 & & \\
\hline F Beliefs & .18 & & & & & & .03 \\
\hline F Career Salience & -.03 & & & & & & .00 \\
\hline M Career Salience & -.06 & & & & & & .00 \\
\hline Step 2 & & .34 & .12 & .06 & .09 & 1.90 & \\
\hline F Beliefs & .14 & & & & & & .02 \\
\hline F Career Salience & -.04 & & & & & & .00 \\
\hline M Career Salience & -.06 & & & & & & .00 \\
\hline F Parental Sat. & .04 & & & & & & .00 \\
\hline M Parental Sat. & -.18 & & & & & & .03 \\
\hline F Efficacy & $.23 *$ & & & & & & .04 \\
\hline M Efficacy & .09 & & & & & & .01 \\
\hline Step 3 & & .39 & .16 & .05 & .04 & 1.47 & \\
\hline F Beliefs & .09 & & & & & & .01 \\
\hline F Career Salience & -.01 & & & & & & .00 \\
\hline M Career Salience & -.04 & & & & & & .00 \\
\hline F Parental Sat. & -.03 & & & & & & .00 \\
\hline M Parental Sat. & -.13 & & & & & & .01 \\
\hline F Efficacy & $.26^{*}$ & & & & & & .05 \\
\hline M Efficacy & .07 & & & & & & .00 \\
\hline M Beliefs & .07 & & & & & & .00 \\
\hline F Marital Sat. & .07 & & & & & & .00 \\
\hline M Marital Sat. & -.12 & & & & & & .01 \\
\hline F Work/Family & -.18 & & & & & & .02 \\
\hline M Work/Family & .03 & & & & & & .00 \\
\hline Step 4 & & .45 & .20 & .08 & .04 & 1.65 & \\
\hline F Beliefs & .06 & & & & & & .00 \\
\hline F Career Salience & .02 & & & & & & .00 \\
\hline M Career Salience & -.10 & & & & & & .01 \\
\hline F Parental Sat. & -.01 & & & & & & .00 \\
\hline M Parental Sat. & -.15 & & & & & & .01 \\
\hline F Efficacy & .23 & & & & & & .03 \\
\hline M Efficacy & .07 & & & & & & .00 \\
\hline M Beliefs & .03 & & & & & & .00 \\
\hline F Marital Sat. & .07 & & & & & & .00 \\
\hline M Marital Sat. & -.12 & & & & & & .01 \\
\hline F Work/Family & -.15 & & & & & & .01 \\
\hline M Work/Family & .01 & & & & & & .00 \\
\hline F Hours & -.16 & & & & & & .02 \\
\hline M Hours & .17 & & & & & & .02 \\
\hline
\end{tabular}

Note. $\mathrm{F}=$ Fathers' reports, $\mathrm{M}=$ Mothers' reports, Beliefs $=$ Scores on Beliefs Concerning the Parental Role scale, , Career Salience $=$ Scores on Career Saliency scale, , Parental Sat. = Scores on Parenting Satisfaction subscale, Efficacy = Scores on Parenting Self-Efficacy subscale, Marital Sat. = Scores on Kansas Marital Satisfaction scale, Work/Family = Scores on Work-Family Conflict scale, Hours = Hours worked/week.

$* p<.05 . N=109$. 
Predictors of Paternal Involvement

Table 5

Results of Hierarchical Regression Analyses Predicting Paternal Responsibility

\begin{tabular}{|c|c|c|c|c|c|c|c|}
\hline Variables & $\beta$ & $R$ & $R^{2}$ & $\operatorname{Adj} . R^{2}$ & $\Delta R^{2}$ & $F$ & $s r_{i}$ \\
\hline Step 1 & & .35 & .12 & .09 & $4.71 * *$ & & \\
\hline F Beliefs & $.28 * *$ & & & & & & .08 \\
\hline F Career Salience & .10 & & & & & & .01 \\
\hline M Career Salience & .14 & & & & & & .02 \\
\hline Step 2 & & .43 & .18 & .12 & .06 & $3.17 * *$ & \\
\hline F Beliefs & .21 & & & & & & .03 \\
\hline F Career Salience & .05 & & & & & & .00 \\
\hline M Career Salience & .18 & & & & & & .03 \\
\hline F Parental Sat. & -.03 & & & & & & .00 \\
\hline M Parental Sat. & .02 & & & & & & .00 \\
\hline F Efficacy & $.26^{*}$ & & & & & & .05 \\
\hline M Efficacy & -.16 & & & & & & .02 \\
\hline Step 3 & & .45 & .20 & .10 & .02 & $2.04 *$ & \\
\hline F Beliefs & .18 & & & & & & .02 \\
\hline F Career Salience & .08 & & & & & & .01 \\
\hline M Career Salience & .19 & & & & & & .03 \\
\hline F Parental Sat. & -.11 & & & & & & .01 \\
\hline M Parental Sat. & .05 & & & & & & .00 \\
\hline F Efficacy & $.28 *$ & & & & & & .05 \\
\hline M Efficacy & -.19 & & & & & & .02 \\
\hline M Beliefs & .03 & & & & & & .00 \\
\hline F Marital Sat. & .00 & & & & & & .00 \\
\hline M Marital Sat. & .05 & & & & & & .00 \\
\hline F Work/Family & -.16 & & & & & & .02 \\
\hline M Work/Family & .01 & & & & & & .00 \\
\hline Step 4 & & .57 & .33 & .23 & .13 & $3.29 * * *$ & \\
\hline F Beliefs & .14 & & & & & & .01 \\
\hline F Career Salience & .13 & & & & & & .02 \\
\hline M Career Salience & .10 & & & & & & .01 \\
\hline F Parental Sat. & -.05 & & & & & & .00 \\
\hline M Parental Sat. & .00 & & & & & & .00 \\
\hline F Efficacy & $.23 *$ & & & & & & .03 \\
\hline M Efficacy & -.18 & & & & & & .02 \\
\hline M Beliefs & -.03 & & & & & & .00 \\
\hline F Marital Sat. & -.01 & & & & & & .00 \\
\hline M Marital Sat. & .05 & & & & & & .00 \\
\hline F Work/Family & -.09 & & & & & & .00 \\
\hline M Work/Family & -.03 & & & & & & .00 \\
\hline F Hours & $-.31 * *$ & & & & & & .08 \\
\hline M Hours & $.25^{*}$ & & & & & & \\
\hline
\end{tabular}

Note. $\mathrm{F}=$ Fathers' reports, $\mathrm{M}=$ Mothers' reports, Beliefs $=$ Scores on Beliefs Concerning the Parental Role scale, Career Salience $=$ Scores on Career Saliency scale, Parental Sat. = Scores on Parenting Satisfaction subscale, Efficacy = Scores on Parenting Self-Efficacy subscale, Marital Sat. = Scores on Kansas Marital Satisfaction scale, Work/Family = Scores on Work-Family Conflict scale, Hours $=$ Hours worked/week.

${ }^{*} p<.05 .{ }^{* *} p<.01 .{ }^{* * *} p<.001 . N=109$. 
Table 6

Results of Hierarchical Regression Analyses Predicting Percentage of Time as the Child's Primary Caregiver

\begin{tabular}{|c|c|c|c|c|c|c|c|}
\hline Variables & $\beta$ & $R$ & $R^{2}$ & $\operatorname{Adj} . R^{2}$ & $\Delta R^{2}$ & $F$ & $s r_{i}^{2}$ \\
\hline Step 1 & & .28 & .08 & .05 & & $3.03 *$ & \\
\hline F Beliefs & $.26^{*}$ & & & & & & .07 \\
\hline F Career Salience & -.04 & & & & & & .00 \\
\hline M Career Salience & .08 & & & & & & .01 \\
\hline Step 2 & & .41 & .17 & .11 & .09 & $2.93 *$ & \\
\hline F Beliefs & .19 & & & & & & .03 \\
\hline F Career Salience & -.07 & & & & & & .00 \\
\hline M Career Salience & .11 & & & & & & .01 \\
\hline F Parental Sat. & -.02 & & & & & & .00 \\
\hline M Parental Sat. & -.03 & & & & & & .00 \\
\hline F Efficacy & $.32 * *$ & & & & & & .08 \\
\hline M Efficacy & -.04 & & & & & & .00 \\
\hline Step 3 & & .48 & .23 & .13 & .06 & $2.39 *$ & .02 \\
\hline F Beliefs & .16 & & & & & & .02 \\
\hline F Career Salience & -.02 & & & & & & .00 \\
\hline M Career Salience & .11 & & & & & & .01 \\
\hline F Parental Sat. & -.11 & & & & & & .01 \\
\hline M Parental Sat. & .03 & & & & & & .00 \\
\hline F Efficacy & $.38 * *$ & & & & & & .10 \\
\hline M Efficacy & -.07 & & & & & & .00 \\
\hline M Beliefs & .10 & & & & & & .01 \\
\hline F Marital Sat. & -.08 & & & & & & .00 \\
\hline M Marital Sat. & .08 & & & & & & .00 \\
\hline F Work/Family & -.20 & & & & & & .03 \\
\hline M Work/Family & .13 & & & & & & .01 \\
\hline Step 4 & & .61 & .37 & .27 & .14 & $3.88 * * *$ & \\
\hline F Beliefs & .10 & & & & & & .01 \\
\hline F Career Salience & .01 & & & & & & .00 \\
\hline M Career Salience & .01 & & & & & & .00 \\
\hline F Parental Sat. & -.07 & & & & & & .00 \\
\hline M Parental Sat. & .03 & & & & & & .00 \\
\hline F Efficacy & $31 * *$ & & & & & & .06 \\
\hline M Efficacy & -.10 & & & & & & .01 \\
\hline M Beliefs & -.01 & & & & & & .00 \\
\hline F Marital Sat. & -.07 & & & & & & .00 \\
\hline M Marital Sat. & .06 & & & & & & .00 \\
\hline F Work/Family & -.20 & & & & & & .02 \\
\hline M Work/Family & .07 & & & & & & .00 \\
\hline F Hours & -.17 & & & & & & .02 \\
\hline M Hours & $.39 * * *$ & & & & & & .11 \\
\hline \multicolumn{8}{|c|}{$\begin{array}{l}\text { Note. } \mathrm{F}=\text { Fathers' reports, } \mathrm{M}=\text { Mothers' reports, Beliefs }=\text { Scores on Beliefs Concerning the Parental Role } \\
\text { scale, Career Salience = Scores on Career Saliency scale, Parental Sat. = Scores on Parenting Satisfaction } \\
\text { subscale, Efficacy = Scores on Parenting Self-Efficacy subscale, Marital Sat. = Scores on Kansas Marital } \\
\text { Satisfaction scale, Work/Family = Scores on Work-Family Conflict } \text { scale, Hours = Hours worked/week. } \\
{ }^{*} p<.05 .{ }^{* *} p<.01 .{ }^{* *} p<.001 . N=109 .\end{array}$} \\
\hline
\end{tabular}


$=.10, \Delta R^{2}=.02$. Fathers' efficacy in the parental role $\left(\beta=28, s r_{i}{ }^{2}=.05\right)$ significantly predicted the amount of responsibility fathers took in childcare. Twenty-three percent of the variance in paternal responsibility was explained when the number of hours mothers and fathers worked outside the home were added to the equation, $F(14,94)=3.29, p<.001, R=.57, A d j . R^{2}=.23, \Delta R^{2}=.13$. Fathers' efficacy in childcare $\left(\beta=23, s r_{i}^{2}=.03\right)$, fathers' work hours $\left(\beta=31, s r_{i}^{2}=.08\right)$, and mothers' work hours $\left(\beta=25, s r_{i}^{2}=.05\right)$ significantly predicted paternal responsibility.

Predictors of the Percentage of Time Fathers' Served as the Child's Primary Caregiver. As shown in Table 6, the first equation accounted for $5 \%$ of the variance in the percentage of time fathers served as the child's primary caregiver, $F(3,105)=$ $3.03, p<.05, R=.28, A d j . R^{2}=.05$. The only significant predictor was fathers' beliefs concerning the parental role $\left(\beta=26, s r_{i}{ }^{2}=.07\right)$. The second equation, that included skills and self-confidence in addition to motivational variables, was also significant, $F(7,101)=2.93, p<.05, R=.41$, Adj. $R^{2}=.11, \Delta R^{2}=.09$. Fathers' efficacy in the parental role $\left(\beta=32, s r_{i}^{2}=.08\right)$ was the only significant predictor in the second step. Adding the social support and stresses variables to the earlier variables accounted for $13 \%$ of the variance, $F(12,96)=2.39, p<.05, R=.48, \operatorname{Adj} . R^{2}=.13$, $\Delta R^{2}=.06$. The only significant predictor of the percentage of time that fathers served as the child's primary caregiver was fathers' efficacy in the parental role ( $\beta=$ $\left.38, s r_{i}{ }^{2}=.10\right)$. The fourth equation in which all four types of influences hypothesized by Lamb and colleagues (1987) were entered into the equation accounted for $27 \%$ of the variance in the percentage of time that fathers served as the child's primary caregiver, $F(14,94)=3.88, p<.001, R=.61, A d j . R^{2}=.27, \Delta R^{2}=.14$. Both fathers' efficacy in childcare $\left(\beta=31, s r_{i}{ }^{2}=.06\right)$ and the number of hours mothers' worked outside the home $\left(\beta=39, s r_{i}^{2}=.11\right)$ significantly predicted the percentage of time men served as the child's primary caregiver.

\section{DISCUSSION}

The present study extended McBride et al.'s (2004) earlier work by examining associations between the categories of influence described by Lamb and colleagues (1987), men's involvement with their young children across three types of father involvement (i.e., engagement, accessibility, and responsibility), and the percentage of time men spent as their children's primary caregiver. McBride et al. argued that, in the absence of motivation, the other influences may not be an issue; therefore, a particular focus of the present study was how fathers' motivation to be involved with their children was associated with reported levels of father involvement.

\section{MOtivationAL FACTORS}

Similar to previous research that has demonstrated the importance of men's beliefs about the fathering role as related to paternal involvement (e.g., Aldous et al., 1998; Crouter et al., 1987; Fox \& Bruce, 2001; McBride et al., 2004; Nangle et al., 2003), nontraditional beliefs about fathering were consistently positively related to all 
aspects of father involvement examined (i.e., engagement, accessibility, responsibility, and time as the child's primary caregiver). In addition, more nontraditional beliefs about the fathers' role predicted more time as the child's primary caregiver. In contrast, few relationships were found between mothers' beliefs about their spouse's involvement in childcare and father involvement. Although it is not possible to determine causation with the present data, results support the premise that childrearing is generally self-determined. An alternative explanation is that men's beliefs about fathering become more liberal as fathers become more involved with their children and that their motivation is not causing more or less involvement. Clearly, however, these results indicate a need for future research to examine fathers' motivation and parental self-confidence in relation to paternal involvement.

In contrast to our hypotheses, however, higher levels of career saliency were not related to involvement in childcare. Previous research on men's career saliency and paternal involvement with children has been inconsistent. It is possible that other factors, such as men's beliefs about fathering, may be more important for paternal involvement as opposed to career saliency per se. It is also important to note the low alpha for the career saliency scale that may have undermined the ability to find associations between this construct and paternal involvement.

\section{SKILlS AND SELF-CONFIDENCE}

Similar to previous research (e.g., Beitel \& Parke, 1998; Ehrenberg et al., 2001), men's parenting self-efficacy was correlated with all types of father involvement examined in the present study. Moreover, fathers' efficacy in childcare predicted paternal responsibility and the percentage of time fathers acted as primary caregivers for their children. Results of the hierarchical regressions also revealed that fathers' parenting self-efficacy was the only predictor to remain stable throughout the steps. Previous research has shown that mothers with high parenting self-efficacy were more responsive and stimulating with their children (Donovan, 1981; Donovan \& Leavitt, 1985; Unger \& Wandersman, 1985) and demonstrated better parenting interactions with their children (Mash \& Johnston, 1983). Although the present data examined quantity of involvement (as opposed to quality of involvement), parenting self-efficacy may also be important for understanding men's involvement with their young children. In contrast to men's parenting self-efficacy, men's satisfaction with parenting did not correlate with the aspects of father involvement investigated.

\section{SOCIAL SUPPORT AND STRESSES}

Men's work-family conflict was not associated with paternal involvement. It is possible that low reliability for the work-family conflict and career saliency scales may have attenuated the ability to find significant associations with these variables. Because many fathers appear highly involved in childcare, greater attention should be given to the concept of work-family conflict in men. 


\section{INSTITUTIONAL FACTORS}

The greater number of hours men worked outside the home, the less responsibility fathers took for childcare. Similar to the findings from previous studies (e.g., Beitel \& Parke, 1998; Bonney et al., 1999; Pleck, 1997), the more hours mothers worked outside the home, the more accessible fathers were to their children, the more responsibility fathers took in childcare, and the more time fathers served as the child's primary caregiver (Beitel \& Parke, 1998; Bonney et al., 1999; Pleck, 1997). Moreover, mothers' work hours predicted the amount of responsibility men took for childcare and the percentage of time fathers acted as primary caregiver for their child. It is interesting to note that the only variable reported by mothers that contributed to father involvement in the regression analyses was the number of hours she worked outside the home. These results continue to indicate the importance of structural variables, in particular men's and women's work hours, for father involvement.

\section{StUdy Limitations AND StREngths}

The present study examined only temporal aspects of father involvement. Several researchers, most notably Hawkins and colleagues (Hawkins et al., 2002; Hawkins \& Palkovitz, 1999), have called for the need to explore broader, more diverse aspects of father involvement (e.g., providing spiritual leadership, psychological support). Undoubtedly, father involvement includes cognitive and affective as well as behavioral components. Related to this issue, we asked parents to report on primary caregiving by one parent that was mutually exclusive of the care provided by the other parent. Future research should consider times in which both parents are available (e.g., accessible) to the child. Moreover, the measure of responsibility for parenting was a measure of who generally took responsibility for occasional as opposed to daily activities (e.g., scheduling pediatrician appointments). A number of researchers (e.g., Coltrane, 1996) have discussed the distinction between implementing childcare tasks and noticing what needs to be done and "directing" childcare.

In addition, data were collected through self-report only. The fact that the survey was anonymous and fathers' and mothers' perceptions of fathers' involvement in childcare were correlated suggests that parents were candid in their responses. Nevertheless, future research should employ behavioral observation. This is important because it may be especially difficult for participants to evaluate fathers' level of sensitivity and connection with their children (i.e., engagement) via self-report.

In addition, the sample included two-parent dual-earner couples who used licensed childcare. Furthermore, the sample consisted primarily of white, upper-middle class families. Therefore, these findings may not generalize to many other types of families, especially those of other races/ethnicities and economic standings. While the sample was homogeneous from the perspective of collecting only data from families in which both parents worked and whose child attended licensed childcare, the sample was heterogeneous in other respects. The number of children in the family and the target child's age varied. Certainly, children at the extreme ends of the age range sampled have different developmental needs that may place different demands on parenting. However, post hoc analyses did not reveal significant associations 
between paternal involvement and child age or child birth order. Still, these family and child differences may have obfuscated some potential associations.

Common to this type of research, the response rate was low. The low response rate may reflect that fathers, in particular, may be unlikely to participate in nonincentive studies. Nevertheless, participation bias represents a threat to the integrity of the study. We also examined how work and parent variables predicted father involvement. All data, however, were collected contemporaneously. Clearly, causality cannot be established. In addition, there were many types of influences on father involvement that we did not examine, including the ways in which child behavior influences father involvement.

The present study also has several methodological strengths. Independent reports were gathered from both mothers and fathers. For the most part, the measures used were well established and reliable. The present research was also more theoretically and conceptually driven than much of the previous literature, and a relatively large sample of families were surveyed. Moreover, correlational analyses support much of the previous research examining father involvement in childcare.

Although investigators have examined the determinants of paternal involvement, these studies often focus on structural (e.g., fathers' time at work) and attitudinal variables (e.g., beliefs about gender roles) that determine the percentage of time men spend in childcare relative to their partners. As men continue to reconstruct their identities and fathering roles to meet contemporary expectations (see Silverstein, Auerbach, \& Levant, 2002), additional research is needed to understand men's involvement in different aspects of fathering. A number of leading researchers have called for investigators to broaden the definition and measurement of fathering (e.g., Cabrera et al., 2000).

In conclusion, the present study suggests that a number of variables set forth by Lamb and colleagues (1987) may influence fathers' involvement in childcare. In particular, these results suggest that men's motivation for fathering (i.e., beliefs about the degree to which men should be involved in fathering), men's skills in the fathering role (i.e., self-efficacy in the parenting role), and institutional factors (i.e., partners' work hours) are correlated with reports of paternal involvement. Although the number of hours that men and women spend in work has been shown to influence fathers' involvement in childcare, the present study suggests that the more the fathers held nontraditional beliefs about their role and the more efficacious men perceived themselves in the parenting role, the more responsibility they took for childcare and the greater percentage of time they served as the child's primary caregiver. Few relationships were found between mothers' beliefs about their spouse's involvement in childcare. Thus, these results support the premise that men's involvement in childcare appears mostly self-determined.

\section{REFERENCES}

Aldous, J., Mulligan, G.M., \& Bjarnason, T. (1998). Fathering over time: What makes the differences? Journal of Marriage and the Family, 60, 809-820. 
Allen, S.M., \& Hawkins, A.J. (1999). Maternal gatekeeping: Mothers' beliefs and behaviors that inhibit greater father involvement in family work. Journal of Marriage \& the Family, 61, 199-212.

Barnett, R.C., \& Baruch, G.K. (1987). Determinants of fathers' participation in family work. Journal of Marriage and the Family, 49, 29-40.

Beitel, A., \& Parke, R. (1998). Parental involvement in infancy: The role of maternal and paternal attitudes. Journal of Family Psychology, 12, 268-288.

Bernas, K.H., \& Major, D.A. (2000). Contributors to stress resistance: Testing a model of women's work-family conflict. Psychology of Women Quarterly, 24, 170-178.

Baruch, G.K., \& Barnett, R.C. (1981). Fathers' participation in the care of their preschool children. Sex Roles, 7, 1043-1055.

Berry, J.O., \& Rao, J.M. (1997). Balancing employment and fatherhood. Journal of Family Issues, 18, 386-403.

Bonney, J.F. (1997). A model of paternal involvement in child care and household labor. Unpublished thesis, Old Dominion University, Norfolk, VA.

Bonney, J.F., Kelley, M.L., \& Levant, R.F. (1999). A model of fathers' behavioral involvement in child care in dual-earner families. Journal of Family Psychology, 13, 401-415.

Cabrera, N.J., Tamis-LeMonda, C.S., Bradley, R.H., Hofferth, S., \& Lamb, M.E. (2000). Fatherhood in the twenty-first century. Child Development, 71, 127136.

Coltrane, S. (1996). Family man: Fatherhood, housework, and gender equity. New York: Oxford.

Cook, J.L., Jones, R.M., Dick, A.J., \& Singh, A. (2005). Revisiting men's role in father involvement: The importance of personal expectations. Fathering: A Journal of Theory, Research, and Practice about Men as Fathers, 3, 165-178.

Crouter, A.C., Perry-Jenkins, M., Huston, T., \& McHale, S.M. (1987). Processes underlying father involvement in dual-earner and single-earner families. Developmental Psychology, 23, 431-440.

Cutrona, C.E., \& Troutman, B. R. (1986). Social support, infant temperament, and parenting self-efficacy: A mediational model of postpartum depression. Child Development, 57, 1507-1518.

Doherty, W., Kouneski, E.F., \& Erickson, M.F. (1998). Responsible fathering: An overview and conceptual framework. Journal of Marriage and the Family, 60, 277-292.

Donovan, W.L. (1981). Maternal learned helplessness and physiologic response to infant crying. Journal of Personality and Social Psychology, 40, 919-926.

Donovan, W.L., \& Leavitt, L.A. (1985). Simulating conditions of learned helplessness: The effects of interventions and attributions. Child Development, 56, 594603.

Donovan, W.L., Leavitt, L.A., \& Walsh, R.O. (1990). Maternal self-efficacy: Illusory control and its effect on susceptibility to learned helplessness. Child Development, 61, 1638-1647. 
JACOBS and KeLLEY

Downer, J.T., \& Mendez, J.L. (2005). African American father involvement and preschool children's social readiness. Early Education and Development, 16, 317-340.

Dubowitz, H., Black, M.M., Cox, C.E., Kerr, M.A., Litrownik, A.J., Radhakrishna, A., et al. (2001). Father involvement and children's functioning at age 6 years: A multisite study. Child Maltreatment: Journal of the American Professional Society on the Abuse of Children, 6, 300-309.

Ehrenberg, M.F., Gearing-Small, M., Hunter, M.A., \& Small, B.J. (2001). Childcare task division and shared parenting attitudes in dual-earner families with young children. Family Relations: Interdisciplinary Journal of Applied Family Studies, 50, 143-153.

Feldman, S.S., Nash, S.C., \& Aschenbrenner, B.G. (1983). Antecedents of fathering. Child Development, 54, 1628-1636.

Flouri, E., \& Buchanan, A. (2003a). The role of father involvement in children's later mental health. Journal of Adolescence, 26, 63-78.

Flouri, E., \& Buchanan, A. (2003b). The role of mother involvement and father involvement in adolescent bullying behavior. Journal of Interpersonal Violence, $18,634-644$.

Fox, G.L., \& Bruce, C. (2001). Conditional fatherhood: Identity theory and parental investment theory as alternative sources of explanation of fathering. Journal of Marriage and the Family, 63, 394-403.

Frone, M.R., Yardley, J.K., \& Markel, K.S. (1997). Developing and testing an integrative model of the work-family interface. Journal of Vocational Behavior, 50, 145-167.

Gibaud-Wallston, J., \& Wandersman, L.P. (1978, August). Development and utility of the parenting sense of competence scale. Paper presented at the meeting of the American Psychological Association, Toronto.

Greenhaus, J.H. (1971). An investigation of the role of career salience in vocational behavior. Journal of Vocational Behavior, 1, 209- 216.

Greenhaus, J.H., \& Simon, W.E. (1977). Career salience, work values, and vocational indecision. Journal of Vocational Behavior, 10, 104-110.

Hart, M.S., \& Kelley, M.L. (2006). Fathers' and mothers' work and family issues as related to internalizing and externalizing behavior of children attending daycare. Journal of Family Issues, 27, 252-270.

Hawkins, A.J., Bradford, K.P., Palkovitz, R., Christiansen, S.L., Day, R.D., \& Call, R.A.V. (2002). The inventory of father involvement: A pilot study of a new measure of father involvement. The Journal of Men's Studies, 10, 183-196.

Hawkins, A.J., \& Palkowitz, R. (1999). Beyond "ticks and clicks": The need for more diverse and broader conceptualizations and measures of father involvement. The Journal of Men's Studies, 8, 11-32.

Hill, E., Hawkins, A.J., Martinson, V., \& Ferris, M. (2003). Studying "working fathers": Comparing fathers' and mothers' work-family conflict, fit, and adaptive strategies in a global high-tech company. Fathering: A Journal of Theory, Research, and Practice about Men as Fathers, 1, 239-261.

Hochschild, A.R. (1997). The time bind: When work becomes home, and home becomes work. New York: Metropolitan Books. 
Hofferth, S. (2003). Race/ethnic differences in father involvement in two-parent families: Culture, context, or economy? Journal of Family Issues, 24, 185-216.

Hoffman, L.W. (1989). Effects of maternal employment in the two-parent family. American Psychologist, 44, 283-292.

Hudson, D.B., Elek, S.M., \& Fleck, M.O. (2001). First-time mothers' and fathers' transition to parenthood: Infant care self-efficacy, parenting satisfaction and infant sex. Issues in Comprehensive Pediatric Nursing, 24, 31-43.

Johnston, C., \& Mash, E.J. (1989). A measure of parenting satisfaction and efficacy. Journal of Clinical Child Psychology, 18, 167-175.

Jump, T.L., \& Haas, L. (1987). Fathers in transition: Dual-career fathers participating in child-care. In M. Kimmel (Ed.), Changing men: New research on men and masculinity (pp. 98-114). Beverly Hills, CA: Sage.

Kalil, A., Ziol-Guest, K.M., \& Coley, R.L. (2005). Perceptions of father involvement patterns in teenage-mother families: Predictors of links to mothers' psychological adjustment. Family Relations: Interdisciplinary Journal of Applied Family Studies, 54, 197-211.

Kopelman, R.E., Greenhaus, J.H., \& Connelly, T.F. (1983). Model of work, family, and interrole conflict: A construct validation study. Organizational Behavior and Human Performance, 32, 198-215.

Lamb, M.E., Pleck, J.H., Charnov, E.L., \& Levine, J.A. (1985). Paternal behavior in humans. American Zoologist, 25, 883-894.

Lamb, M.E., Pleck, J.H., Charnov, E.L., \& Levine, J.A. (1987). A biosocial perspective on paternal behavior and involvement. In J. Lancaster, J. Altmann, A. Rossi, \& L. Sherrod (Eds.), Parenting across the lifespan: Biosocial dimensions (pp. 111-142). New York: Aldine de Gruyter.

Levy-Shiff, R., \& Israelashvili, R. (1988). Antecedents of fathering: Some further exploration. Developmental Psychology, 24, 434-440.

Marsiglio, W. (1991). Paternal engagement activities with minor children. Journal of Marriage and the Family, 41, 287-299.

Mash, E.J., \& Johnston, C. (1983). The prediction of mothers' behavior with their hyperactive children during play and task situations. Child and Family Behavior Therapy, 5, 1-14.

McBride, B.A., \& Mills, G. (1993). A comparison of mother and father involvement with their preschool age children. Early Childhood Research Quarterly, 8, 457477.

McBride, B.A., Schoppe-Sullivan, S.J., \& Ho, M. (2005). The mediating role of fathers' school involvement on student achievement. Journal of Applied Developmental Psychology, 26, 201-216.

Mezulis, A.H., Hyde, J.S., \& Clark, R. (2004). Father involvement moderates the effect of maternal depression during a child's infancy on child behavior problems in kindergarten. Journal of Family Psychology, 18, 575-588.

Milkie, M.A., Bianchi, S.M., Mattingly, M.J., \& Robinson, J.P. (2002). Gendered division of childrearing: Ideals, realities, and the relationship to parental wellbeing. Sex Roles, 47, 21-38. 
Minton, C., \& Pasley, K. (1996). Fathers' parenting role identity and father involvement: A comparison of nondivorced and divorced, nonresident fathers. Journal of Family Issues, 17, 26-45.

Nangle, S.M., Kelley, M.L., Fals-Stewart, W., \& Levant, R.L. (2003). Work and family variables as related to paternal engagement, responsibility, and accessibility in dual-earner couples with young children. Fathering: A Journal of Theory, Research, and Practice about Men as Fathers, 1, 71-90.

Noor, N.M. (2004). Work-family conflict, work and family role salience, and women's well-being. Journal of Social Psychology, 144, 389-405.

Nordenmark, M. (2004). Does gender ideology explain differences between countries regarding the involvement of women and of men in paid and unpaid work? International Journal of Social Welfare, 13, 233-243.

Ohan, J.L., Leung, D.W., \& Johnston, C. (2000). The Parenting Sense of Competence scale: Evidence of a stable factor structure and validity. Canadian Journal of Behavioural Science, 32, 251-261.

Parke, R.D. (2002). Fathers and families. In M.H. Bornstein (Ed.), Handbook of parenting: Vol. 3: Being and becoming a parent (2nd ed., pp. 27-73). Mahwah, NJ: Erlbaum.

Parke, R.D., Dennis, J., Flyr, M.L., Morris, C., Killian, C., McDowell, D.J., et al. (2004). Fathering and children's peer relationships. In M.E. Lamb (Ed.), The role of the father in child development (4th ed., pp. 307-340). Hoboken, NJ: Wiley.

Pleck, J.H. (1997). Paternal involvement: Levels, sources, and consequences. In M.E. Lamb (Ed.), The role of the father in child development (3rd ed., pp. 66103). New York: Wiley.

Pleck, J.H., \& Masciadrelli, B.P. (2004). Paternal involvement by U.S. residential fathers: Levels, sources, and consequences. In M.E. Lamb (Ed.), The role of the father in child development (4th ed., pp. 222-271). Hoboken, NJ: John Wiley \& Sons.

Pleck, E.H., \& Pleck, J.H. (1997). Fatherhood ideals in the United States: Historical dimensions. In M.E. Lamb (Ed.), The role of the father in child development (3rd ed., pp. 33-48). New York: Wiley.

Radin, N., \& Goldsmith, R. (1985). Caregiving fathers of preschoolers: Four years later. Merrill-Palmer Quarterly, 31, 375-383.

Russell, G. (1983). The changing role of fathers? St. Lucia, Queensland: University of Queensland Press.

Russell, G., \& Hwang, C.P. (2004). The impact of workplace practices on father involvement. In M.E. Lamb (Ed.), The role of the father in child development (4th ed., pp. 476-503). New York: Wiley.

Sagi, A. (1982). Antecedents and consequences of various degrees of paternal involvement in child rearing: The Israeli project. In M.E. Lamb (Ed.), Nontraditional families: Parenting and child development (pp. 205-222). Hillsdale, NJ: Erlbaum.

Sandberg, J.F., \& Hofferth, S.L. (2001). Changes in children's time with parents: United States, 1981-1997. Demography, 38, 423-436.

Sanderson, S., \& Thompson, V.L.S. (2002). Factors associated with perceived paternal involvement in childrearing. Sex Roles, 46, 99-111. 
Schumm, W.R., Paff-Bergen, L.A., Hatch, R. C., Obiorah, F.C., Copeland, M., Meens, L.D., et al. (1986). Concurrent and discriminant validity of the Kansas Marital Satisfaction Scale. Journal of Marriage and the Family, 48, 381-398.

Silverstein, L.B., Auerbach, C.F., \& Levant, R.F. (2002). Contemporary fathers reconstructing masculinity: Clinical implications of gender role strain. Professional Psychology: Research \& Practice, 33, 361-369.

Tabachnick, B.G., \& Fidell, L.S. (2001). Using multivariate statistics (4th ed.). Boston: Allyn and Bacon.

Unger, D.G., \& Wandersman, L.P. (1985). Social support and adolescent mothers: Action research contributions to theory and application. Journal of Social Issues, 41, 29-45.

U.S. Department of Labor (2004). Mothers in the labor force, 1955-2004. Retrieved on April 20, 2005, from: http://www.infoplease.com/ipa/A0104670.html.

Wenk, D., Hardesty, C.L., Morgan, C.S., \& Blair, S.L. (1994). The influence of parental involvement on the well-being of sons and daughters. Journal of Marriage and the Family, 56, 228-234.

Yeung, W., Sandberg, J.F., Davis-Kean, P.E., \& Hofferth, S.L. (2001). Children's time with fathers in intact families. Journal of Marriage and the Family, 63, 136-154. 